Screening of glycoside hydrolases and ionic liquids for fibre modification

Rahikainen, Jenni

2018-03

Rahikainen , J Anbarasan , S , Wahlström , R , Parviainen , A , King , A W T , Puranen , T , Kruus , K, Kilpeläinen , I , Turunen , O \& Suurnäkki , A 2018 , ' Screening of glycoside hydrolases and ionic liquids for fibre modification ' , Journal of Chemical Technology and pÿBiotechnology , vol. 93 , no. 3 , pp. 818826 . https://doi.org/10.1002/jctb.5435

http://hdl.handle.net/10138/307279

https://doi.org/10.1002/jctb.5435

acceptedVersion

Downloaded from Helda, University of Helsinki institutional repository.

This is an electronic reprint of the original article.

This reprint may differ from the original in pagination and typographic detail.

Please cite the original version. 


\section{Screening of glycoside hydrolases and ionic liquids for fibre}

\section{2 modification}

3 Jenni Rahikainen ${ }^{\mathrm{a}}$, Sasikala Anbarasan ${ }^{\mathrm{b}}$, Ronny Wahlström ${ }^{\star a}$, Arno Parviainen ${ }^{\mathrm{c}}$, Alistair W.T.

4 King $^{\mathrm{c}}$, Terhi Puranen ${ }^{\mathrm{d}}$, Kristiina Kruus ${ }^{\mathrm{a}}$, Ilkka Kilpeläinen ${ }^{\mathrm{c}}$, Ossi Turunen ${ }^{\mathrm{b}}$, Anna Suurnäkki $^{\mathrm{a}, \mathrm{e}}$

5 aVTT Technical Research Centre of Finland Ltd, Tietotie 2, P.O. Box 1000, FI-02044 VTT,

6 Finland

7 balto University, School of Chemical Engineering, P.O. Box 16100, FI-00076 AALTO,

8 Espoo, Finland

9 'University of Helsinki, Department of Chemistry, P.O. Box 55, Fl-00014 University of 10 Helsinki, Finland

$11{ }^{\mathrm{d} R O A L}$ Oy, Tykkimäentie 15b, 05200 Rajamäki, Finland

$12{ }^{e}$ Current address: Metsä Fibre Oy, Revontulenpuisto 2, 02100 Espoo, Finland

$13{ }^{*}$ corresponding author, +358400254073

14 jenni.rahikainen@vtt.fi, sasikala.anbarasan@gmail.com, ronny.wahlstrom@vtt.fi

15 arno.parviainen@helsinki.fi, alistair.king@helsinki.fi, terhi.puranen@roal.fi,

16 kristiina.kruus@vtt.fi, ilkka.kilpelainen@helsinki.fi, ossi.turunen@aalto.fi,

17 anna.suurnakki@metsagroup.com

18 Key words: ionic liquid, cellulase, endoglucanase, xylanase, fibre modification, CBM

19 Abstract 
1 BACKGROUND: This study elaborates the possibility to apply combined ionic liquid and

2 enzyme treatments for pulp fibre modification. The approach involves swelling of fibre

3 surfaces with ionic liquid (IL) followed by enzymatic modification of the disrupted fibre

$4 \quad$ surface using carbohydrate active enzymes.

5 RESULTS: The capacity of seven cellulose-dissolving or cellulose-swelling ionic liquids to

6 swell pulp fibres was compared. In addition, thirteen cellulases and five xylanases were

7 screened for their IL tolerance, which determines their applicability in combined or sequential

8 IL-enzyme treatments of fibres. Among the studied ionic liquids, 1-ethyl-3-methylimidazolium

9 dimethylphopshate ([EMIM]DMP) and 1,3-dimethylimidazolium dimethylphosphate

10 ([DMIM]DMP) had the strongest effect on fibre swelling. These solvents were also found to

11 be the least inactivating for the studied enzymes.

12 CONCLUSION: Enzyme compatibility and cellulose-dissolving capability are not two 13 conflicting properties of an ionic liquid.

\section{Introduction}

15 Replacement of non-renewable materials such as oil-based plastics with renewable

16 biomass-based alternatives is a global trend. Utilization of cellulose pulp fibres in new and

17 unconventional material applications is appealing both for the forest industry, looking for new business opportunities, and for the end product manufacturers looking for industrially available, well performing and sustainable raw materials. New methods for fibre modification are required to broaden the properties of cellulosic fibres to meet the requirements of various

21 material applications.

High accessibility and reactivity of polysaccharides in fibres is required in applications such as cellulose-based composites or man-made cellulose fibres produced via dissolution and 
1 regeneration stages. Cellulose in wood fibres is densely packed at all of its structural levels,

2 from elementary fibrils to the lamellar fibre structure. Different mechanical, chemical and

3 enzymatic approaches may be used to loosen the dense packing. Pulp reactivity

4 characterized by fibre dissolution in cellulose solvents is reported to increase with

5 mechanical and enzymatic treatments. ${ }^{1,2}$ On the other hand, cellulose solvents, such as

6 ionic liquids (ILs) can be used to swell and disrupt fibre surfaces. ${ }^{3}$

7 One of the most interesting developments in cellulose chemistry during the last decades is

8 the discovery of cellulose-dissolving ionic liquids (ILs). ${ }^{4}$ ILs are salts with low melting points

$9\left(<100^{\circ} \mathrm{C}\right)$. The combination of organic and ionic character makes ILs excellent solvents in

10 various applications. The negligible vapour pressure of ILs reduces emissions of volatile

11 organic compounds and reduces explosion hazards related to many organic solvents. Thus,

12 ILs possess clear benefits as cellulose solvents from an industrial point of view. Currently,

13 research is ongoing to study fibre spinning from IL solutions for textile applications ${ }^{5}$, which

14 might yield a new technology alternative to the Lyocell process, in which cellulose fibres are

15 spun from $\mathrm{N}$-methylmorpholine $\mathrm{N}$-oxide (NMMO) solution. In addition to complete

16 dissolution, fibre swelling in ILs is an interesting alternative for fibre processing. ${ }^{6}$

17 Endoglucanases (EC 3.2.1.4) are a group of cellulose-degrading enzymes able to internally

18 cleave the $\beta-1,4-$ glycosidic bonds in cellulose chains. As a side activity, many

19 endoglucanases are also able to degrade hemicellulosic plant polymers such as xylan and

20 glucomannan. ${ }^{7}$ Endoglucanases from different structural families differ in their mode of

21 action ${ }^{8}$ and surface modification of pulps with enzymes from different families has been

22 studied. ${ }^{9,10}$ For instance, the beatability and viscosity of chemical pulp was affected

23 differently by different endoglucanases from Trichoderma reesei. ${ }^{10}$ Endoglucanase

24 treatments have been reported to improve the alkaline solubility of dissolving pulp by

25 carefully controlled hydrolysis of the cellulose chains. ${ }^{11}$ 
1 Xylanases (EC 3.2.1.8) are hydrolytic enzymes that catalyse the hydrolysis of $\beta-1,4-$

2 glycosidic linkage connecting the anhydroxylose units in xylan. In fibre treatment xylanases

3 are not only involved in xylan removal, but also assist in fibre modification. Hardwood pulp

4 fibres treated with xylanases showed external fibrillation that could contribute to increase the

5 interfibre bonds ${ }^{12}$, improved resistance to pressing, higher tendency of fibre hornification

6 and collapsibility during drying. ${ }^{13}$ In addition, fibre porosity can be increased with a xylanase

7 treatment. ${ }^{14}$

8 Enzymatic catalysis of various reactions has been successfully carried out in IL solutions. ${ }^{15}$

9 In recent years the use of enzymes together with cellulose-dissolving ILs has been studied

10 intensively, although difficult compatibility issues have been reported for the combination of

11 ILs and glycoside hydrolases (GHs). ${ }^{16}$ Discoveries of more IL-tolerant enzymes have been

12 reported and correlation of IL-tolerance with enzyme thermostability ${ }^{17,18}$, salt-tolerance ${ }^{19}$

13 and alkali-tolerance ${ }^{20}$ have been suggested.

14 In this study, our aim was to use activating or swelling ILs in sequence with enzymatic

15 treatments for modification of fibre surfaces (Fig. 1). In this article, we report the first part of

16 this study that is, screening of 13 endoglucanases and 5 xylanases in aqueous solutions of 7

17 different cellulose-swelling or dissolving ILs. Enzymes were chosen from different glycoside

18 hydrolase $(\mathrm{GH})$ families to explore whether $\mathrm{GH}$ family was a key enzyme characteristic for IL

19 tolerance. Thermostable enzymes were favoured based on previous literature suggestions.

$20 \quad 17$ The swelling of pulp fibres was studied in the same ILs and the results were combined

21 with the enzymatic screening to identify the most potential IL-enzyme combinations for both

22 swelling pulp fibres and supporting sufficient enzymatic activity for efficiently modifying the

23 fibre surfaces in a one-pot system. 


\section{Materials and Methods}

\section{Ionic liquids, pulps and enzymes}

3 Seven ILs, known to dissolve or swell cellulose, were synthesized with the exception of

4 [DMIM]DMP, which was purchased from loLiTec GmbH (Heidelberg, Germany). Structures

5 and full names of the studied ILs are presented in Table 1. The ${ }^{1} \mathrm{H}$ NMR spectra of

6 [BMIM]DBP, [Chol]AcO, [BMIM]DMP, [TMGH]n-PrCOO and [EMIM]DMP are shown in

7 the supplementary material (Fig. S1-S5).

1-Butyl-3-methylimidazolium dibutylphosphate [BMIM]DBP was prepared as follows: 1methylimidazole $(20.59 \mathrm{~g}, 0.2515 \mathrm{~mol})$ was weighed into a $250 \mathrm{ml}$ 3-neck round bottom flask. The solution was heated up to $100^{\circ} \mathrm{C}$ and tributyl phosphate $(66.83 \mathrm{~g}, 0.2509 \mathrm{~mol})$ was slowly added using a pressure-equalising dropping funnel. The system was under positive pressure of argon. The reaction was then heated to $140^{\circ} \mathrm{C}$ and left to stir for $80 \mathrm{hrs}$. The sample was then cooled to $120^{\circ} \mathrm{C}$ for $66 \mathrm{hrs}$. The progress of the reaction was monitored using ${ }^{1} \mathrm{H}$ NMR (Fig. S1). Cholinium acetate [Chol]AcO was prepared as follows: Choline bicarbonate $(191.49 \mathrm{~g}, 0.91 \mathrm{~mol}, 80 \%(\mathrm{w} / \mathrm{w})$ in water) was weighed into a round bottom flask and diluted to about double the total volume with distilled water. Glacial acetic acid $(55.69 \mathrm{~g}$, $0.91 \mathrm{~mol}$ ) was slowly added to the mixture while stirring. The progress of the reaction was monitored using ${ }^{1} \mathrm{H}$ NMR to ensure that there was a 1:1 mol ratio of cholinium cation to acetate anion (Fig. S2). 1-Butyl-3-methylimidazolium dimethylphosphate [BMIM]DMP was prepared as follows: $59.37 \mathrm{~g}(0.478 \mathrm{~mol})$ of butylimidazole was weighed into a $250 \mathrm{ml}$ 3-neck round bottom flask. The solution was slowly heated up to $100^{\circ} \mathrm{C}$ while slowly adding $66.83 \mathrm{~g}(0.477 \mathrm{~mol})$ of tributylphosphate using addition funnel. The reaction was left to stir at $140^{\circ} \mathrm{C}$ for 80 hours. The progress of the reaction was followed by using ${ }^{31} \mathrm{P}$ and ${ }^{1} \mathrm{H}$ NMR (Fig. S3). 1,1,3,3-Tetramethylguanadinium butyrate [TMGH]n-PrCOO was prepared as follows: Distilled 1,1,3,3-tetramethylguanidine (56.66 g, 0.492 mol) was 
1 slowly mixed (over $15 \mathrm{~min}$ ) with butanoic acid $(43.34 \mathrm{~g}, 0.492 \mathrm{~mol})$. The mixture was

2 thoroughly mixed and allowed to cool, to form [TMGH]n-PrCOO. The product was

3 characterized using ${ }^{1} \mathrm{H}$ NMR (Fig. S4). 1-Ethyl-3-methylimidazolium

4 dimethylphosphate [EMIM]DMP was prepared as follows: 1-Ethylimidazole (45.96 g,

$50.478 \mathrm{~mol}$ ) was weighed into a 3-neck round bottom flask. The solution was heated up to

$6 \quad 100^{\circ} \mathrm{C}$ and trimethyl phosphate $(66.83 \mathrm{~g}, 0.477 \mathrm{~mol})$ was slowly added using a pressure-

7 equalising dropping funnel. The reaction was left to stir at $120^{\circ} \mathrm{C}$ for 80 hours. The

8 progress of the reaction was followed using ${ }^{1} \mathrm{H}$ NMR (Fig. S5). Tetrabutylphosphonium

9 acetate [P4444]AcO was prepared by anion metathesis, according to a previous article

$10{ }^{21}$. Briefly, anion metathesis from the commercially available tetrabutylphosphonium

11 chloride (1 eq), using potassium acetate (1.05 eq) in isopropanol, was performed. An

12 additional acetone precipitation step was used to precipitate excess potassium salts.

13 Filtration through celite and evaporation yielded the pure ionic liquid. Purity was followed

14 by ${ }^{1} \mathrm{H}$ NMR (DMSO- $\left.\mathrm{d}_{6}\right)$ to determine acetate to cation ratio and using Karl-Fischer

15 titration to ensure the water content was below $1 \%(w / w)$.

Bleached softwood kraft pulp and hardwood dissolving pulp were obtained from two separate Finnish pulp mills as dry pulp sheets.

The studied endoglucanases and xylanases are listed in Table 2 with the available characterization data. Trichoderma reesei endoglucanases ( $\mathrm{TrGH} 5$ and $\mathrm{TrGH} 7$ ) were purified from $T$. reesei culture filtrates. ${ }^{10}$ The $P$. horikoshii enzyme $(\mathrm{PhGH} 5)$ was heterologously expressed in E. coli and partially purified using heat treatment. ${ }^{22}$ The TfXYN10A construct was obtained from ROAL Oy and produced in E.coli. TmXYN10A ${ }^{23}$ was kindly provided as a lyophilized culture supernatant from Hairong Xiong (South-central 
1 produced in E.coli at Aalto University. The other enzymes were obtained from commercial

2 sources or as pre-commercial preparates from ROAL Ltd. as indicated in Table 2.

\section{Enzyme screening}

4 Screening of endoglucanase and xylanase activities in the presence of ILs was done using

5 miniaturized assays in $500 \mu \mathrm{L}$ 96-well polypropylene microplates (Eppendorf $\mathrm{GmbH}$,

6 Germany). Carboxymethyl cellulose (CMC) and birchwood xylan were used as substrates for

7 endoglucanases and xylanases, respectively. Enzymes were dosed to reactions based on

8 their activity. Activity necessary to hydrolyse $1-2 \%$ of the substrate polymer in the absence of

9 IL was determined and this dosing was used in all reactions. Reactions were performed in

$10200 \mu \mathrm{L}$ volume followed by an assay of reducing sugars. A miniaturized version of the

11 dinitrosalicylic acid (DNS) method 25 was used except with one ionic liquid, [P4444]AcO.

12 This IL was found to be more compatible with the $p$-hydroxybenzoic acid hydrazide

13 (PAHBAH) assay. ${ }^{26}$ Glucose or xylose was used as standard for the reducing sugar assay

14 and standard solutions were always prepared to the same IL solution that was used in the

15 enzyme assay.

16 Endoglucanases were assayed using 1\% (w/v) carboxymethylcellulose (Sigma) as substrate

17 in sodium citrate buffer $(\mathrm{pH} 5)$ containing $0 \%, 15 \%$ or $40 \%(\mathrm{w} / \mathrm{v})$ of ionic liquid. Buffer

18 strengths $50 \mathrm{mM}$ and $200 \mathrm{mM}$ were used with $15 \%$ and $40 \%(\mathrm{w} / \mathrm{v}) \mathrm{IL}$ concentrations,

19 respectively. ILs were found to increase the $\mathrm{pH}$ of the solution (Table 1) and $50 \mathrm{mM}$ citric acid was used to adjust $\mathrm{pH}$ to the range 5-6. Among the studied ILs [Chol]AcO, [TMGH]nPrCOO and [P4444]AcO were the most alkaline ones and pH adjustment with citric acid was unsuccessful when $40 \%$ of these ionic liquids was present. Therefore, endoglucanase activities in these conditions were measured without $\mathrm{pH}$ adjustment and $\mathrm{pH}$ in these reactions was in the range $7-8$. 
1 Xylanase activities were assayed using $2 \%$ birchwood xylan as substrate (Sisco Research

2 Laboratories Ltd., India) in $50 \mathrm{mM}$ phosphate buffer $(\mathrm{pH} 7)$ containing 0,15 or $40 \%(\mathrm{w} / \mathrm{v})$ of

3 ionic liquid. To check the activity of the enzyme with different concentrations of ILs, the pH

4 was adjusted to 7 after the addition of IL, using $50 \mathrm{mM}$ phosphoric acid.

5 Assay temperatures $50^{\circ} \mathrm{C}$ and $60^{\circ} \mathrm{C}$ were used for endoglucanases and xylanases,

6 respectively. For $P$. horikoshii endoglucanase, T. maritima xylanase and $D$. thermophilum

7 xylanases $70^{\circ} \mathrm{C}$ assay temperature was used due to drastically decreasing activity in lower

8 temperatures. Bovine serum albumin (BSA, $0.1 \mathrm{mg} / \mathrm{mL}$ ) was added to each reaction to

9 prevent unspecific enzyme binding to plate wells. Two hours incubation time with no

10 agitation was applied for all sample plates. All reactions were carried out in triplicates.

\section{Pulp swelling in aqueous ionic liquid solutions}

12 Dry pulp sheets were homogenized by soaking them in water ( $1 \mathrm{~g}$ pulp/ $66 \mathrm{~g}$ of water) for 4 hours. The wet pulps were disintegrating using an electric kitchen mixer, followed by dewatering by vacuum filtration on a $60 \mu \mathrm{m}$ wire cloth. After dewatering the homogenized pulps had dry contents of ca. $50 \%$.

For swelling/dissolution experiments, $10-20 \mathrm{mg}$ (dry weight) of homogenized pulp was weighed into a glass test tube. Water and IL were added, taking into account the water present in the pulp, to form a pulp dispersion in $90 \%(\mathrm{w} / \mathrm{w}) \mathrm{IL}$. The pulp dispersion in aqueous IL was heated to $80^{\circ} \mathrm{C}$ and subjected to magnetic stirring for $3 \mathrm{~h}$ in sealed test tubes in a temperature-controlled water bath. Samples were taken for light microscopy examination after $180 \mathrm{~min}$. Light microscopy was performed with an Olympus BX61 microscope (Olympus Corp., Japan) and digital image recording was performed with the Soft Imaging Systems analySIS1 3.2 software. 


\section{Results and discussion}

\section{Screening aqueous ionic liquids for pulp swelling}

3 The effect of IL treatment on pulp swelling was evaluated with seven ionic liquids from light

4 microscopy images (Table 1). Representative microscopy images after each treatment are

5 shown in the supplementary material (Fig. S6 and Fig. S7). The imidazolium and phosphate-

6 based ILs were found to be the most effective in generating visually detectable changes in

7 pulp morphology in the following order [EMIM]DMP $>$ [DMIM]DMP $>[B M I M] D M P$. Thus in the

8 imidazolium-based ILs, longer alkyl chains in the IL structure correlated with lower fibre

9 swelling capacity. Previously, longer carboxylate chain lengths in IL anions have been found

10 to prevent cellulose dissolution. ${ }^{27}$ Minor changes were detected after pulp treatment with

$11[\mathrm{TMGH}] \mathrm{n}-\mathrm{PrCOO}$ and $[\mathrm{P} 4444] \mathrm{AcO}$, whereas no visual changes were detected after treatment with [BMIM]DBP and [Chol]AcO. Pulp swelling was found to occur via two distinctive mechanisms as shown in Fig. 2. Fig. 2 A shows ballooning-type fibre swelling which typically occurred in the middle of fibres and Fig. 2 B shows unwinding which typically occurred at fibre ends. Unwinding was the most prominent mechanism observed with birch dissolving pulp whereas ballooning was more prominent with softwood kraft pulp.

Ballooning-type of swelling has been previously described to occur for cotton and wood fibres in ionic liquid solutions. ${ }^{6}$ In ballooning, S2 layer of the secondary cell wall is suggested to swell faster compared to the S1 layer, which causes the lower layer to burst out and form balloon structures to the fibre. ${ }^{28}$ Recalcitrance of individual fibres to changes caused by the IL treatments was found to vary significantly (Fig. 2). Although only a minority of the fibres showed visible changes after IL treatment, these changes can be expected to change the bulk properties of the pulp. 


\section{Screening of endoglucanases and xylanases for ionic liquid}

2 tolerance/compatibility

3 The hydrolytic performance of 13 endoglucanases and 5 xylanases was studied in the

4 presence of seven cellulose-dissolving or swelling ILs. Enzymes were selected to represent

5 different glycoside hydrolase $(\mathrm{GH})$ families to ensure a broad variation in the enzyme

6 structures. For endoglucanases, $\mathrm{GH}$ families 5,7,12, and 45, and for xylanases, $\mathrm{GH}$ families

$7 \quad 10$ and 11 were represented (Table 2). Enzymes of bacterial and fungal origin were involved

8 and special attention was paid to involve enzymes with notable thermostability due to the

9 previously suggested correlation between thermostability and IL-tolerance. ${ }^{17,29} \mathrm{~A}$

10 miniaturized screening assay was developed to allow high throughput operation and to

11 minimize the use of ILs and enzymes in the screening. A long assay time (2h) was chosen to reflect factors related to both enzyme activity and stability in the aqueous IL solution.

\section{Screening of endoglucanases}

Hydrolysis of carboxymethyl cellulose (CMC) with 13 endoglucanases was studied in the presence of $15 \%(w / v)$ of ionic liquids (Fig. 3). Six enzymes from different GH families with promising IL-tolerance were chosen for an additional screening round with $40 \%(\mathrm{w} / \mathrm{v})$ ILs

(Fig. 4). Results are shown as relative activities (\%), the $100 \%$ level representing enzyme activity in a pH 5 buffer solution. An averaged value of activity in the presence of different ILs was calculated for each enzyme aiming to describe the overall IL-tolerance of the enzyme (Fig. 3 and Fig. 4).

Enzyme activity in the presence of 15 and $40 \%$ (w/v) ILs varied widely between endoglucanases, ranging from complete enzyme inactivation ( $0 \%$ relative activity) to an activating effect (>100\% relative activity) (Fig. 3 and Fig. 4). In most cases, ILs reduced the activity of endoglucanases. Interestingly, some enzymes were found to be activated in the presence of [DMIM]DMP, [BMIM]DMP and [TMGH]n-PrCOO. 
1 An averaged value of relative activity was calculated for each enzyme which represents the

2 overall stability of the enzyme in the presence of all studied ILs (last rows in Fig. 3 and 4).

3 According to the averaged activity values, PhGH5 and 1_GH45+CBM were the most IL-

4 tolerant enzymes in the presence of $15 \%(w / v)$ and $40 \%(w / v)$ of ILs. Both enzymes, PhGH5

5 and 1_GH45+CBM, originate from thermophilic organisms, i.e. from the extremophile

6 bacterium $P$. horikoshii and from a thermotolerant fungus, respectively. For PhGH5, good IL

7 tolerance has been reported previously. ${ }^{17}$ In all cases, good thermostability alone did not

8 result in good IL tolerance. The commercial endoglucanases CtGHX, TmGH5 and DtGHX

9 from thermophilic bacteria Clostridium thermocellum, Thermotoga maritima and

10 Dictyoglomus turgidum, respectively, had the poorest IL tolerance among the studied enzymes. Less than $20 \%$ of relative activity (averaged value) was retained in the presence of $15 \%(\mathrm{w} / \mathrm{v})$ of the ILs. Endoglucanases $\mathrm{TrGH} 7$ and $\mathrm{TrGH} 5$ from the mesophilic and industrially important organism Trichoderma reesei retained $57 \%$ and $44 \%$ of activity (averaged values) in the presence of $15 \%(\mathrm{w} / \mathrm{v}) \mathrm{IL}$, respectively. $\mathrm{TrGH} 7$ (former EGI) was found to be generally more IL tolerant compared to the other endoglucanase $\mathrm{TrGH} 5$ (former EGII) from T. reesei, although $\mathrm{TrGH} 7$ structure is more labile at elevated temperatures. ${ }^{30} \mathrm{In}$ this study, the most IL-tolerant endoglucanases represented $\mathrm{GH}$ families 5 and 45.

Two structural variants of a 1_GH45 endoglucanase were included in the study, one carrying a family 1 carbohydrate binding module (CBM) linked to a core domain via a peptide linker (1_GH45+CBM) and the other being the same enzyme without a linker and a CBM (1_GH45) (Table 2). At low substrate consistency, CBMs are known to improve cellulase enzyme action on insoluble cellulosic substrates by concentrating the enzymes on substrate surfaces and promoting the formation of enzyme-substrate complexes. The CBM-free variant 1_GH45 reached 39\% relative activity (averaged value) at 40\% (w/v) IL concentration, whereas the corresponding enzyme with a CBM tolerated ILs significantly better (50\%). In general, CBMs do not affect enzyme activity on soluble substrates ${ }^{31}$, which 
1 suggests that the better performance of 1_GH45+CBM is caused by other factors. The

2 carbohydrate binding module in the enzyme 1_GH45+CBM is connected to the catalytic core

3 domain through a linker peptide. The linker peptide is likely highly O-glycosylated in a fungal

4 expression host. ${ }^{32} \mathrm{O}$-glycans have been shown to increase the enzyme resistance to

5 proteolytic cleavage and increase thermostability. ${ }^{33}$ In this study the highly O-glycosylated

6 linker peptide may have shielded the enzyme from the inactivating effect of ILs. When

7 endoglucanase action on solid cellulosic substrate has been studied, ionic liquids are found

8 to interfere with CBM interaction with cellulose. ${ }^{34}$ Accordingly, CBM or linker-bound O-

9 glycans may bring additional structural stability to an enzyme in the presence of ILs but the

10 functional role of CBM in targeted cellulose binding may be compromised.

\section{Screening of xylanases}

12 The hydrolysis efficiency of five $\mathrm{GH} 10$ and $\mathrm{GH} 11$ xylanases were tested in $15 \%(\mathrm{w} / \mathrm{v})$ and 40\% (w/v) IL solutions (Fig. 5 A and Fig. 5 B, respectively). Enzyme tolerance to ILs varied greatly, although the GH10 xylanases (TfXYN10A, TmXYN10B, GH10) showed generally higher IL tolerance ${ }^{23,35}$ over the GH11 xylanases (DtXYN11B, GH11). ${ }^{24}$ Among the studied enzymes TfXYN10A was the most IL-tolerant enzyme retaining $100 \%$ and $48 \%$ of relative activity (averaged) in the presence of $15 \%$ and $40 \% \mathrm{IL}$, respectively. TfXyn10A retained its full activity even in the presence of $15 \%$ [P4444]AcO which was found to be a highly inactivating IL for the other enzymes. TfXyn10A was found to outperform the other xylanases almost in all conditions. This enzyme was earlier shown to have very low competitive inhibition in the presence of [EMIM]OAc, [EMIM]DMP and [DBNH]OAc. ${ }^{36}$ The present study showed that this enzyme tolerates a large array of hydrophilic ILs. Among GH10 xylanases, the order of IL tolerance was TfXYN10A $>$ GH10 $>\operatorname{TmXYN10B}$ and it remained the same in both $15 \%$ and $40 \%$ IL concentrations. Among the two GH11 xylanases DtXyn11B was more IL-tolerant compared to the pre-commercial GH11 xylanase. 
1 Although enzyme thermostability has been correlated with IL-tolerance ${ }^{17}$ the results

2 obtained with $\mathrm{GH} 10$ xylanases highlight also that thermostability does not inherently

3 implicate good IL tolerance. ${ }^{24}$ Among the studied xylanases TmXYN10B was the most

4 thermostable enzyme, but it was not the most IL-tolerant one. However, this enzyme has

5 demonstrated its hydrolytic efficiency in the presence of IL at higher temperatures (80-

$\left.6 \quad 100^{\circ} \mathrm{C}\right) .{ }^{23}$

7 In previous studies and in this study, family $\mathrm{GH} 10$ xylanases were generally found to be

8 more IL-tolerant compared to family GH11 enzymes. ${ }^{35}$ Earlier findings with [EMIM]AcO

9 suggest that the IL interferes with substrate binding in the active site and this competitive

10 inhibition may be more pronounced with family $\mathrm{GH} 11$ xylanases. ${ }^{24}$ The difference in activity

11 among these enzymes in the presence of ILs appears to be based on differences in the

12 active site and was revealed by molecular docking studies between the enzyme and the IL

13 cation. ${ }^{35,36}$ Probably the narrow and deep active site of $\mathrm{GH} 11$ xylanases allows transient

14 binding of a large amounts of $[E M I M]^{+}$cations, thus preventing the binding of a substrate.

15 Consequently, the activity is hindered by competitive inhibition posed by binding of the IL

16 cation. ${ }^{37}$ Jaeger and Pfaendtner (2013) proposed a mechanism based on molecular

17 dynamics simulation that IL cations may bind to some places in the xylanase active site. ${ }^{37}$

18 Later molecular docking studies revealed a much larger number of potential binding sites in

19 the narrow active site canyon of $\mathrm{GH} 11$ xylanases ${ }^{35}$, in which, a large part or even whole

20 active site canyon could be filled with (transiently) bound IL cations. It was also observed

21 that in the wider active site of $\mathrm{GH} 10$ xylanases, the binding of [EMIM] ${ }^{+}$cations is distributed

22 in a more restricted area than in $\mathrm{GH} 11$ xylanases ${ }^{35}$, which is in line with the conclusion of

23 lower competitive inhibition in GH10 enzymes. Nevertheless, the high thermostability

24 probably protects against the structural unfolding effect of ILs also in xylanases. 
1 Comparison of the effect of ionic liquids on enzyme activity and fibre-swelling 2 capability

3 Among the studied ILs, [DMIM]DMP was the most enzyme-compatible IL at $40 \%(\mathrm{w} / \mathrm{v})$ consistency both with endoglucanases and xylanases (Fig. 3 and Fig. 5 B, respectively). In a previous study [DMIM]DMP has been identified as least inhibitory to the studied enzymes among four different ILs. ${ }^{38}$ In this study, the imidazolium and phosphate based ionic liquids [DMIM]DMP, [EMIM]DMP, [BMIM]DMP and [BMIM]DBP shared a similar structural basis except that the anions and cations in the series have growing alkyl side chains (Table 1). There appears to be a clear trend that longer alkyl side chains in the IL structure led to lower compatibility with enzymes. This trend has previously been observed with a series of imidazolium- and phosphate-based ILs. ${ }^{39}$ Within the series of imidazolium- and phosphatebased ILs, [BMIM]DBP, which carries the longest alkyl side chains both in the anion and cation was also least compatible with the studied endoglucanases and xylanases. Among the studied ILs, [P4444]AcO was clearly the most inhibitory to all studied enzymes, both endoglucanases and xylanases, except that TfXyn10A was highly active in it at $15 \%(\mathrm{w} / \mathrm{v}) \mathrm{IL}$ concentration. Tetrabutylphosphonium [P4444] cation carries four four-carbon alkyl chain substituents and the IL is also highly alkaline in aqueous solutions (Table 1), which may be predictive of poor enzyme compatibility. In a recently published study [Chol]AcO has been found to be reasonably cellulase-compatible as compared to [EMIM]AcO. ${ }^{40}$ In this study [Chol]AcO was also among the least toxic of the studied ILs. [TMGH]n-PrCOO has in a previous study been found to be more inactivating for $T$. reesei Cel5A than [EMIM]AcO ${ }^{18}$, while the results in this study place [TMGH]n-PrCOO between the imidazolium-based ILs in terms of enzyme compatibility.

Interestingly, the fibre swelling capacity of the studied ILs appeared to follow the same trend as was the case for enzyme compatibility (Table 1, Fig. 3 and Fig. 4). Especially in the case of the imidazolium-based ILs, longer alkyl substituents on either the IL cation, anion or on both was detrimental to their capability to make visible changes to the fibre morphology, 


\section{Conclusions}

7 The aim of this study was to find ionic liquid (IL) and enzyme combinations that may be used

meaning that the most enzyme-compatible ILs were also the most potential ones for fibre swelling. This can be seen as an encouraging result for making the IL and enzymatic treatment in a one-pot process. The observed effect of alkyl chain length in imidazolium ILs on cellulose-dissolving capacity is in good accordance with results published by Swatloski et al (2002) on a different set of cellulose-dissolving imidazolium ILs. ${ }^{4}$

simultaneously or sequentially to modify pulp fibres. At $40 \%$ (w/v) IL concentration several

IL-enzyme combinations retained more than $50 \%$ of activity. Endoglucanase from hyperthermophilic organism P. horikoshii was found to be highly stable in the presence of ILs together with a family $\mathrm{GH} 45$ endoglucanase (1_GH45+CBM) of fungal origin. Among the studied xylanases, GH10 T. flexuosa xylanase (TfXYN10A) was found to be the most ILtolerant xylanase. In general, family $\mathrm{GH} 10$ xylanases were more IL-tolerant compared to family GH11 xylanases.

ILs with imidazolium- and phosphate-based ions were found to be most effective in fibre swelling. [EMIM]DMP and [DMIM]DMP with the shortest alkyl side-chains were found to be more effective compare to [BMIM]DMP and [BMIM]DBP with longer alkyl side-chains. ILs based on imidazolium cation and phosphate anion were also found to be enzyme-compatible if short-chain alkyl substituents were attached to the core molecules (such as in [DMIM]DMP). Longer alkyl substituents resulted in increased enzyme inactivation and lower fibre-swelling capacity. Most detrimental to enzyme activity were the ILs [BMIM]DBP and [P4444]AcO both rich in long chain alkyl substituents. As groups, the cellulases and xylanases responded partially differently to the presence of different ILs, and it was also noticed that thermostability alone was not indicative of good IL tolerance. For endoglucanases the most IL-tolerant enzymes were from families 5 and 45 whereas 
1 xylanases from $\mathrm{GH}$ family 10 were the most IL-tolerant. For the integrated IL and enzymatic

2 treatment of fibres, it can be considered a promising result that the most suitable fibre-

3 swelling ILs also were the least inactivating ones.

\section{Acknowledgements}

5 Hairong Xiong (South-central University for Nationalities, College of Life Science, Wuhan,

6 China) is acknowledged for providing TmXYN10A for the study. This work was a part of ACel

7 program (Advanced Cellulose to Novel Products) of the CLIC Innovation Ltd. The funding of

8 the Finnish Funding Agency for Technology and Innovation (TEKES) is acknowledged.

\section{$9 \quad$ References}

1. Grönqvist S, Treimanis A, Kamppuri T, Maloney T, Skute M, Grinfelds U, Vehviläinen M,

11 Suurnäkki A, The effect of the outermost fibre layers on solubility of dissolving grade pulp.

12 Cellulose 22:3955-3965 (2015). DOI 10.1007/s10570-015-0709-9

13 2. Henriksson G, Christiernin M, Agnemo R, Monocomponent endoglucanase treatment

14 increases the reactivity of softwood sulphite dissolving pulp. $J$ Ind Microbiol Biotechnol

$15 \quad 32: 211-214$ (2005). DOI 10.1007/s10295-005-0220-7

16 3. Wang $\mathrm{Y}$, Yao $\mathrm{S}$, Jia $\mathrm{C}$, Chen $\mathrm{P}$, Song $\mathrm{H}$, Swelling behaviors of natural cellulose in ionic

17 liquid aqueous solutions. J Appl Polym Sci 131:1-6 (2014). DOI: 10.1002/app.40199

18 4. Swatloski RP, Spear SK, Holbrey JD, Rogers RD, Dissolution of cellulose with ionic

19 liquids. J Am Chem Soc 124:4974-4975 (2002). DOI: 10.1021/ja025790m

20 5. Michund A, Tanttu M, Asaadi S, Ma Y, Netti E, Kääriäinen P, Persson A, Berntsson A,

21 Hummel $\mathrm{M}$, Sixta $\mathrm{H}$, loncell-F: ionic liquid-based cellulosic textile fibres as an alternative to 
1 viscose and Lyocell. Text Res J 86:543-52 (2016).

2 DOI: https://doi.org/10.1177/0040517515591774

3 6. Cuissinat C, Navard P, Heinze T, Swelling and dissolution of cellulose. Part IV: Free

4 floating cotton and wood fibres in ionic liquids. Carbohydr Polym 72:590-596 (2008).

$5 \quad$ DOI:10.1016/j.carbpol.2007.09.029

6 7. Vlasenko E, Schülein M, Cherry J, Xu F, Substrate specificity of family $5,6,7,9$, 12, and

745 endoglucanases. Bioresour Technol 101:2405-2411 (2010).

8 DOI:10.1016/j.biortech.2009.11.057

9 8. Karlsson J, Siika-aho M, Tenkanen M, Tjerneld F, Enzymatic properties of the low 10 molecular mass endoglucanases Cel12A (EG III) and Cel45A (EG V) of Trichoderma reesei. 11 J Biotechnol 99:63-78 (2002). DOI: 10.1016/S0168-1656(02)00156-6

12 9. Dienes D, Börjesson J, Stålbrand H, Réczey K, Production of Trichoderma reesei Cel7B 13 and its catalytic core on glucose medium and its application for the treatment of secondary 14 fibers. Process Biochem 41:2092-2096 (2006). DOI: 10.1016/j.procbio.2006.04.017

15 10. Suurnäkki A, Tenkanen M, Siika-aho M, Niku-Paavola M-L, Viikari L, Buchert J, 16 Trichoderma reesei cellulases and their core domains in the hydrolysis and modification of 17 chemical pulp. Cellulose 7:189-209 (2000). DOI: 10.1023/A:1009280109519

18 11. Kamppuri T, Vehviläinen M, Backfolk K, Heiskanen I, Characterization of endoglucanase 19 rich Trichoderma reesei cellulase mixtures and their effect on alkaline solubility of dissolving pulp. Cellulose 23:3901-3911 (2016). DOI: 10.1007/s10570-016-1055-2 
1 12. Valls C, Gallardo O, Vidal T, Pastor FIJ, Díaz P, Roncero MB, New xylanases to obtain

2 modified eucalypt fibres with high-cellulose content. Bioresour Technol 101:7439-7445

3 (2010). DOI: 10.1016/j.biortech.2010.04.085

4 13. Blomstedt M, Asikainen J, Lahdeniemi A, Ylönen T, Paltakari J, Hakala TK, Effect of 5 xylanase on dewatering properties of birch kraft pulp. Bioresources 5:1164-1177 (2010).

6 14. Suurnäkki A, Li T-Q, Buchert J, Tenkanen M, Viikari L, Vuorinen T, Ödberg L, Effects of

7 Enzymatic Removal of Xylan and Glucomannan on the Pore Size Distribution of Kraft Fibres.

$8 \quad$ Holzforschung 51:27-33 (1997). DOI: 10.1515/hfsg.1997.51.1.27

9 15. van Rantwijk F, Sheldon RA, Biocatalysis in Ionic Liquids. Chem Rev 107:2757-2785

10 (2007). DOI: 10.1021/cr050946x

11 16. Wahlström RM, Suurnäkki A, Enzymatic hydrolysis of lignocellulosic polysaccharides in the presence of ionic liquids. Green Chem 17:694-714 (2015). DOI: 10.1039/C4GC01649A

13 17. Datta S, Holmes B, Park JI, Chen Z, Dibble DC, Hadi M, Blanch HW, Simmons BA,

14 Sapra R, lonic liquid tolerant hyperthermophilic cellulases for biomass pretreatment and 15 hydrolysis. Green Chem 12:338-345 (2010). DOI: 10.1039/b916564a

18. Wahlström R, King A, Parviainen A, Kruus K, Suurnäkki A, Cellulose hydrolysis with

17 thermo- and alkali-tolerant cellulases in cellulose-dissolving superbase ionic liquids. RSC Adv 3:20001-20009 (2013). DOI: 10.1039/c3ra42987c

19. Ilmberger N, Meske D, Juergensen J, Schulte M, Barthen P, Rabausch U, Angelov A, Mientus M, Liebl W, Schmitz RA, Streit WR, Metagenomic cellulases highly tolerant towards

21 the presence of ionic liquids - linking thermostability and halotolerance. App/ Microbiol 
1 20. Trivedi N, Gupta V, Reddy CR, Jha B, Detection of ionic liquid stable cellulase produced

2 by the marine bacterium Pseudoalteromonas $\mathrm{sp}$. isolated from brown alga Sargassum

3 polycystum C. Agardh. Bioresour Technol 132:313-319 (2013). DOI:

$4 \quad$ 10.1016/j.biortech.2013.01.040

5 21. Mikkola S-K, Robciuc A, Lokajová J, Holding AJ, Lämmerhofer M, Kilpeläinen I,

6 Holopainen JM, King AWT, Wiedmer SK, Impact of Amphiphilic Biomass-Dissolving lonic

7 Liquids on Biological Cells and Liposomes. Environ Sci Technol 49:1870-1878 (2015). DOI:

$8 \quad 10.1021 /$ es505725g

9 22. Hämäläinen J, Granström T, Mollerup $F$, Wang $Y$, Xiong $H$, Turunen $O$, Effect of 10 enzymatic high temperature prehydrolysis on the subsequent cellulose hydrolysis of steam11 pretreated spruce in high solids concentration. J Chem Technol Biotechnol 91:1844-1852 12 (2016). DOI: 10.1002/jctb.4777

23. Yu T, Anbarasan S, Wang Y, Telli K, Aslan AS, Su Z, Zhou Y, Zhang L, livonen P, 14 Havukainen S, Mentunen T, Hummel M, Sixta H, Binay B, Turunen O, Xiong H, Hyperthermostable Thermotoga maritima xylanase XYN10B shows high activity at high temperatures in the presence of biomass-dissolving hydrophilic ionic liquids. Extremophiles 20:515-524 (2016). DOI: 10.1007/s00792-016-0841-y

24. Li H, Kankaanpää A, Xiong H, Hummel M, Sixta H, Ojamo H, Turunen O,

19 Thermostabilization of extremophilic Dictyoglomus thermophilum $\mathrm{GH} 11$ xylanase by an N-

20 terminal disulfide bridge and the effect of ionic liquid [emim]OAc on the enzymatic

21 performance. Enzyme Microb Technol 53:414-419 (2013). DOI:

10.1016/j.enzmictec.2013.09.004 acid. J Biol Chem 62:287-290 (1924). 
1 26. Lever MA, New Reaction for Colorimetric Determination of Carbohydrates. Anal Biochem 2 47:273-279 (1972). DOI: 10.1016/0003-2697(72)90301-6

3 27. King AWT, Asikkala J, Mutikainen I, Järvi P, Kilpeläinen I, Distillable acid-base conjugate 4 ionic liquids for cellulose dissolution and processing. Angew Chem Int Ed 50:6301-6305 5 (2011). DOI: 10.1002/anie.201100274

6 28. Le Moigne N, Montes E, Pannetier C, Höfte H, Navard P, Gradient in Dissolution 7 Capacity of Successively Deposited Cell Wall Layers in Cotton Fibres. Macromol Symp 8 262:65-71 (2008). DOI: 10.1002/masy.200850207

9 29. Gladden JM, Park JI, Bergmann J, Reyes-Ortiz V, D’haeseleer P, Quirino BF, Sale KL, 10 Simmons BA, Singer SW, Discovery and characterization of ionic liquid-tolerant thermophilic 11 cellulases from a switchgrass-adapted microbial community. Biotechnol Biofuels 7:15.

12 DOI: 10.1186/1754-6834-7-15 30. Baker JO, Tatsumoto K, Grohmann K, Woodward J, Wichert JM, Shoemaker SP, 14 Himmel ME, Thermal denaturation of Trichoderma reesei cellulases studied by differential scanning calorimetry and tryptophan fluorescence. App/ Biochem Biotechnol 34:217-231 (1992). DOI: 10.1007/BF02920547

31. Boraston AB, Bolam DN, Gilbert HJ, Davies GJ, Carbohydrate-binding modules: finetuning polysaccharide recognition. Biochem J 382:769-781. DOI: 10.1042/BJ20040892 $\mathrm{NH}$, Modified glycosylation of cellobiohydrolase I from a high cellulase-producing mutant strain of Trichoderma reesei. Eur J Biochem 256:119-127 (1998). DOI: 10.1046/j.14321327.1998.2560119.x 
1 33. Chen L, Drake MR, Resch MG, Greene ER, Himmel ME, Chaffey PK, Beckham GT, Tan

2 Z, Specificity of O-glycosylation in enhancing the stability and cellulose binding affinity of

3 Family 1 carbohydrate-binding modules. Proc Natl Acad Sci USA 111:7612-7617 (2014).

4 DOI: $10.1073 /$ pnas. 1402518111

5 34. Wahlström R, Rahikainen J, Kruus K, Suurnäkki A, Cellulose hydrolysis and binding with

6 Trichoderma reesei Cel5A and Cel7A and their core domains in ionic liquid solutions.

7 Biotechnol Bioeng 111:726-733 (2014). DOI: 10.1002/bit.25144

8 35. Chawachart N, Anbarasan S, Turunen S, Li H, Khanongnuch C, Hummel M, Sixta H,

9 Granström T, Lumyong S, Turunen O, Thermal behaviour and tolerance to ionic liquid 10 [emim]OAc in GH10 xylanase from Thermoascus aurantiacus SL16W. Extremophiles 11 18:1023-1034 (2014). DOI: 10.1007/s00792-014-0679-0

12 36. Anbarasan S, Wahlström R, Hummel M, Ojamo H, Sixta H, Turunen O. High stability and 13 low competitive inhibition of thermophilic Thermopolyspora flexuosa GH10 xylanase in 14 biomass-dissolving ionic liquids. Appl Microbiol Biotechnol 101:1487-98 (2017). DOI: $15 \quad 10.1007 / \mathrm{s} 00253-016-7922-9$ 37. Jaeger VW, Pfaendtner J, Structure, Dynamics, and Activity of Xylanase Solvated in

17 Binary Mixtures of Ionic Liquid and Water. ACS Chem Biol 8:1179-1186 (2013). DOI: $10.1021 / \mathrm{cb} 3006837$ 38. Engel $P$, Mladenov R, Wulfhorst $H$, Jäger $G$, Spiess AC, Point by point analysis: how ionic liquid affects the enzymatic hydrolysis of native and modified cellulose. Green Chem 12:1959-1966 (2010). DOI: 10.1039/c0gc00135j 
1 39. Zhi S, Liu Y, Yu X, Wang X, Lu X, Enzymatic hydrolysis of cellulose after pretreated by

2 ionic liquids: Focus on one-pot process. Energy Procedia 14:1741-1747 (2011). DOI:

$3 \quad$ 10.1016/j.egypro.2011.12.887

4 40. Ninomiya K, Kohori A, Tatsumi M, Osawa K, Endo T, Kakuchi R, Ogino C, Shimizu N,

5 Takahashi K, lonic liquid/ultrasound pretreatment and in situ enzymatic saccharification of

6 bagasse using biocompatible cholinium ionic liquid. Bioresour Technol 176:169-174 (2015).

$7 \quad$ DOI: $10.1016 /$ j.biortech.2014.11.038

8 41. Anbarasan S, Jänis J, Paloheimo M, Laitaoja M, Vuolanto M, Karimäki J, Vainiotalo P,

9 Leisola M, Turunen O, Effect of Glycosylation and Additional Domains on the Thermostability

10 of a Family 10 Xylanase Produced by Thermopolyspora flexuosa. Appl Environ Microbiol

11 76:356-360 (2010). DOI: 10.1128/AEM.00357-09 
Table 1 lonic liquids (ILs) and their effect on fibre swelling

\begin{tabular}{|c|c|c|c|c|}
\hline Abbreviation & Full name & $\begin{array}{l}\text { Chemical } \\
\text { structure }\end{array}$ & Effect on fibre swelling ${ }^{b}$ & $\begin{array}{l}\mathrm{pH} \text { in assay } \\
\text { conditions }^{\mathrm{a}}\end{array}$ \\
\hline [DMIM]DMP & 1,3-Dimethylimidazolium dimethylphosphate & & +++ & 6 \\
\hline [EMIM]DMP & 1-Ethyl-3-methylimidazolium dimethylphosphate & & ++++ & 6.5 \\
\hline [BMIM]DMP & 1-Butyl-3-methylimidazolium dimethylphosphate & & ++ & $5.5-6$ \\
\hline [BMIM]DBP & 1-Butyl-3-methylimidazolium dibutylphosphate & & 0 & $6-7$ \\
\hline [Chol]AcO & Cholinium acetate & & 0 & 8 \\
\hline$[\mathrm{TMGH}] \mathrm{n}-\mathrm{PrCOO}$ & 1,1,3,3-Tetramethylguanidinium butyrate & & + & $7.5-8$ \\
\hline
\end{tabular}


a $\mathrm{pH}$ value was measured from a mixture of $40 \% \mathrm{IL}$ in $50 \mathrm{mM}$ sodium citrate buffer $(\mathrm{pH} 5)$ using $\mathrm{pH}$ indicator paper

${ }^{b}$ no effect $(0)$, minor effect $(+)$, major effect $(++++)$, effect on dissolving pulp fibres was evaluated from light microscopy images. Examples of representative light microscopy images are available in the supplementary material (Fig. S6 and S7). 
Table 2 Endoglucanases and xylanases used in ionic liquid compatibility screening.

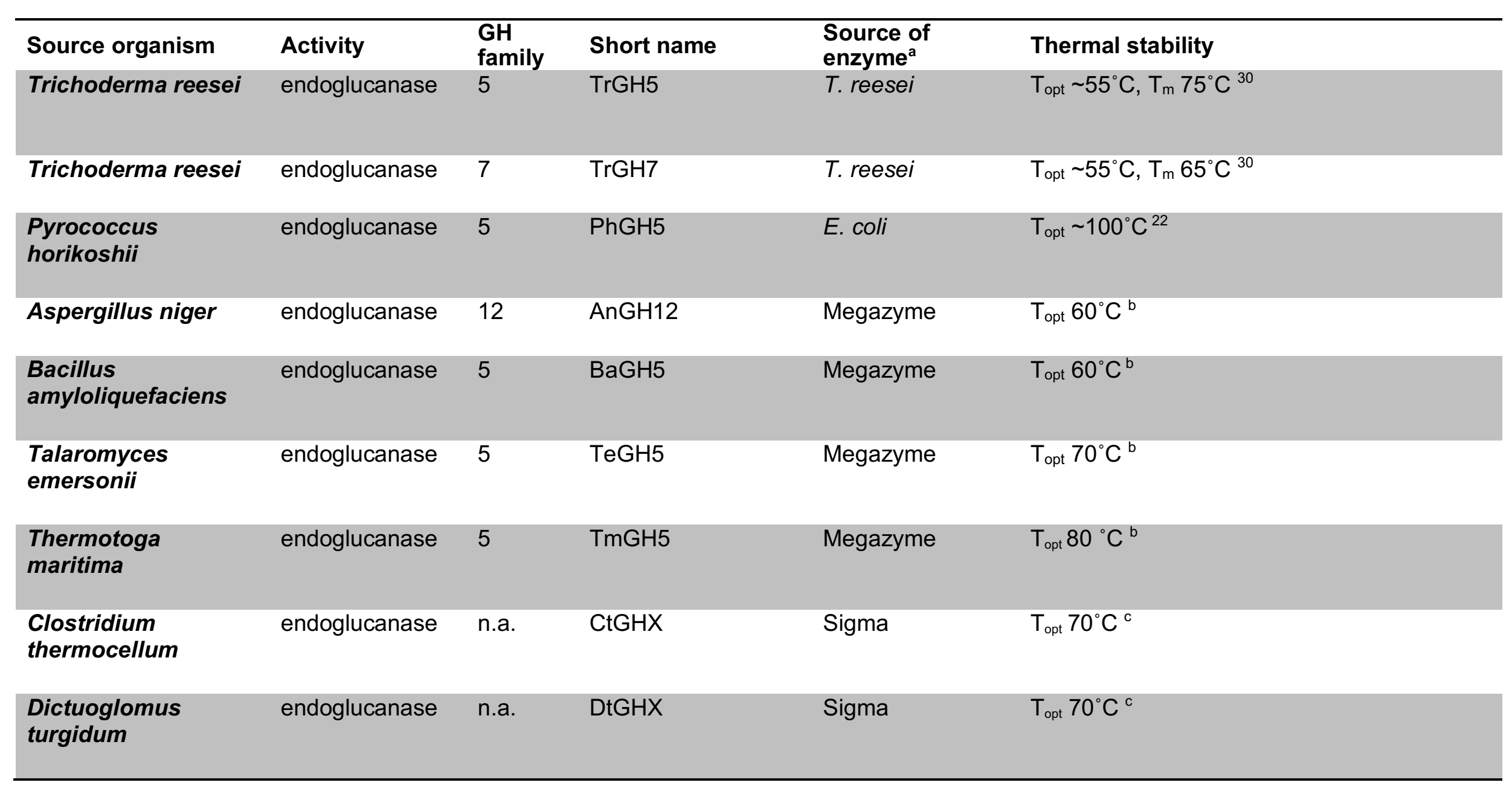




\begin{tabular}{|c|c|c|c|c|c|}
\hline n.a. & endoglucanase & 45 & 1_GH45 & ROAL Oy & $\begin{array}{l}\text { Enzyme from a thermotolerant fungal } \\
\text { species }\end{array}$ \\
\hline n.a. & endoglucanase & 45 & 1_GH45+CBM & ROAL Oy & $\begin{array}{l}\text { Enzyme from a thermotolerant fungal } \\
\text { species }\end{array}$ \\
\hline n.a. & endoglucanase & 45 & 2_GH45 & ROAL Oy & n.a. \\
\hline n.a. & endoglucanase & 5 & $\mathrm{GH} 5$ & ROAL Oy & n.a. \\
\hline $\begin{array}{l}\text { Thermopolyspora } \\
\text { flexuosa }\end{array}$ & xylanase & 10 & Tf Xyn10 & E.coli & Topt $78^{\circ} \mathrm{C}^{41}$ \\
\hline $\begin{array}{l}\text { Thermotoga } \\
\text { maritima MSB8 }\end{array}$ & xylanase & 10 & TmXyn10 & P. pastoris & Topt $100^{\circ} \mathrm{C}^{23}$ \\
\hline $\begin{array}{l}\text { Dictyoglomus } \\
\text { thermophilum }\end{array}$ & xylanase & 11 & DtXyn11 & E.coli & Topt $90^{\circ} \mathrm{C}^{24}$ \\
\hline n.a. & xylanase & 10 & $\mathrm{GH} 10$ & ROAL Oy & n.a. \\
\hline n.a. & xylanase & 11 & GH11 & ROAL Oy & n.a. \\
\hline
\end{tabular}

\footnotetext{
$\mathrm{GH}=$ glycoside hydrolase, n.a. = not available

${ }^{a}$ commercial source or expression host specified, enzymes provided by ROAL Oy are pre-commercial preparates baccording to manufacturer's product sheet

'temperature used in manufacturer's product sheet
} 


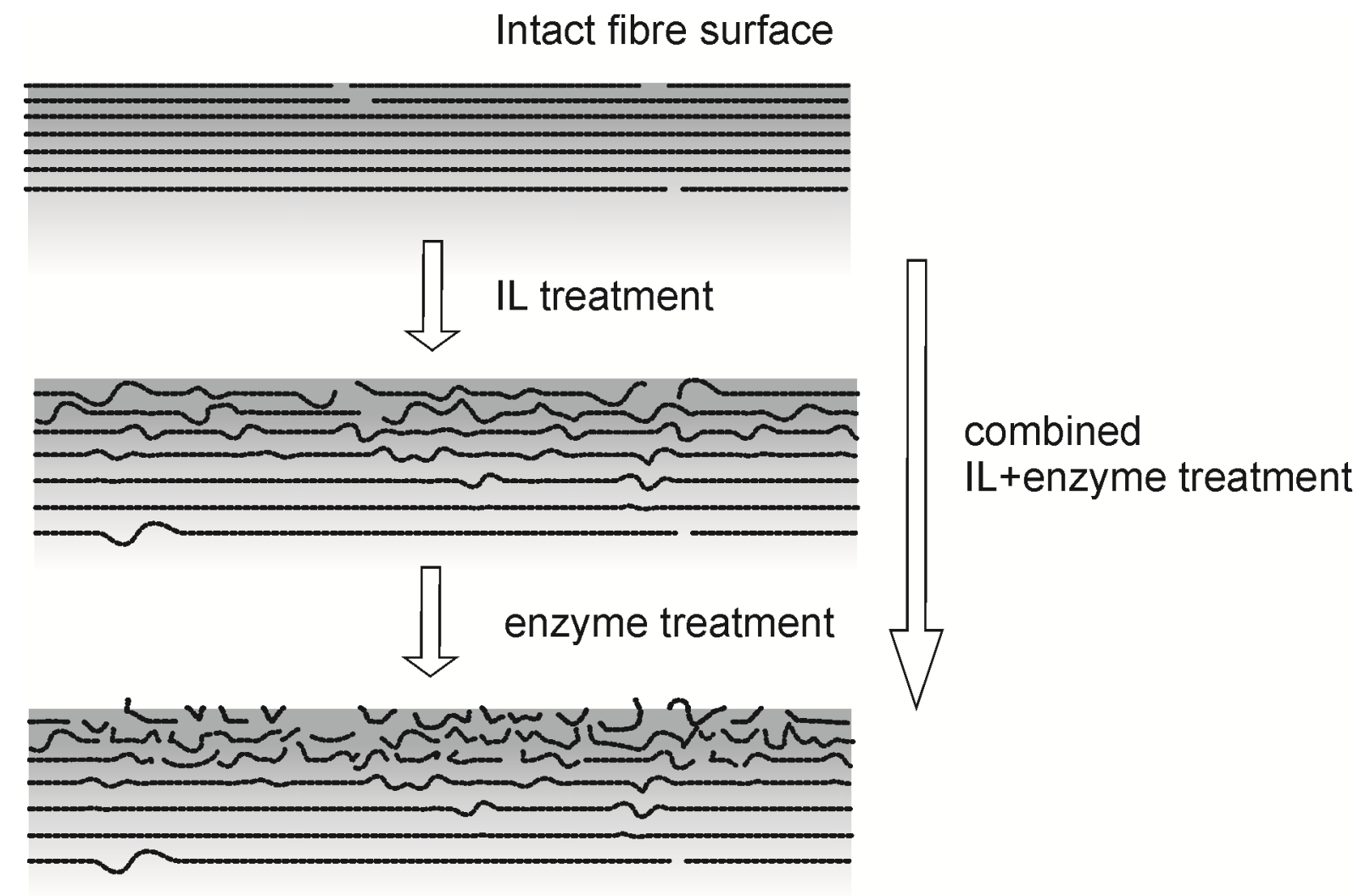

Fig. 1. Envisioned modification of cellulose pulp fibre surfaces by lonic liquid (IL), enzyme treatment and their combinations. 

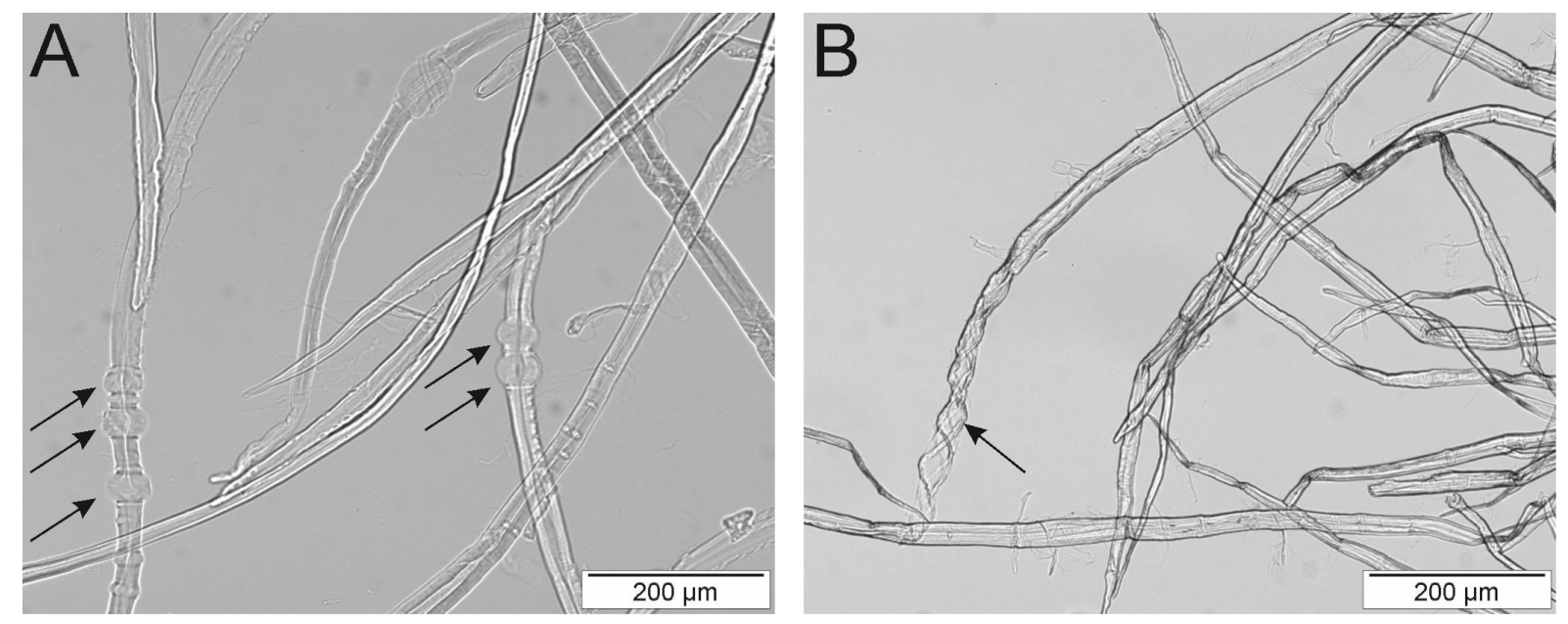

Fig. 2. Swelling of pulp fibres by ionic liquids. Light microscopy images of typical changes in pulp fibres after treatment with ionic liquid. A) Bleached softwood kraft fibre treated with $90 \%$ (w/w) [EMIM]DMP $\left.\left(3 \mathrm{~h}, 80^{\circ} \mathrm{C}\right), \mathrm{B}\right)$ Dissolving pulp treated with $90 \%(\mathrm{w} / \mathrm{w})[\mathrm{TMGH}] \mathrm{n}-\mathrm{PrCOO}$ $\left(3 \mathrm{~h}, 80^{\circ} \mathrm{C}\right)$. Fibre swelling with ballooning (red arrows in panel $\mathrm{A}$ ) and unwinding (red arrow in panel B) mechanisms are shown. 


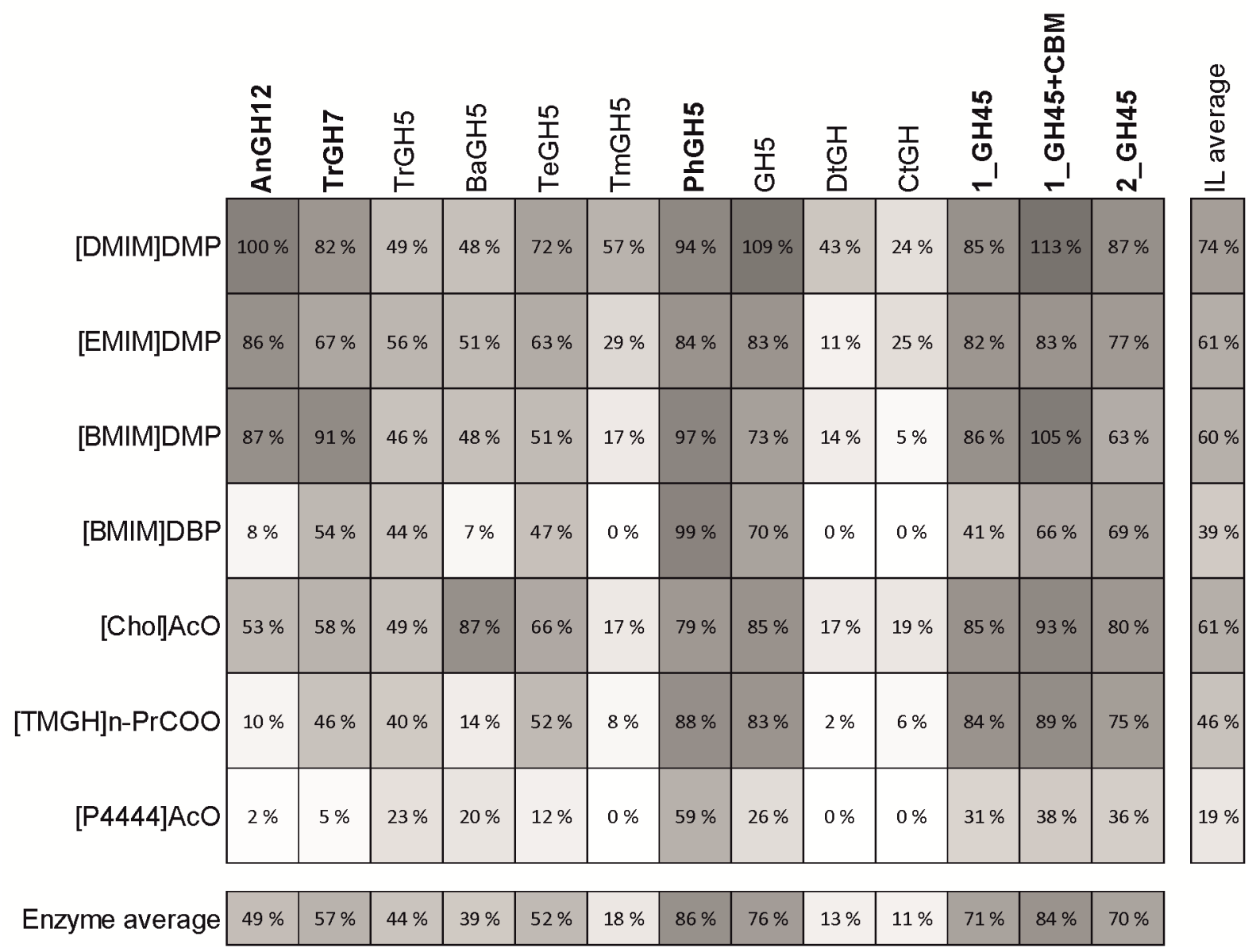

Fig. 3. Action of endoglucanases in $15 \%$ ionic liquid. Relative endoglucanase activities in $15 \%(w / v)$ ionic liquid after a $2 \mathrm{~h}$ assay. Reaction without added IL represents the $100 \%$ level. The darker the grey colour, the higher the enzyme activity in the IL solution. Enzymes marked with boldface were selected for subsequent screening round with $40 \%(\mathrm{w} / \mathrm{v})$ ionic liquid. 


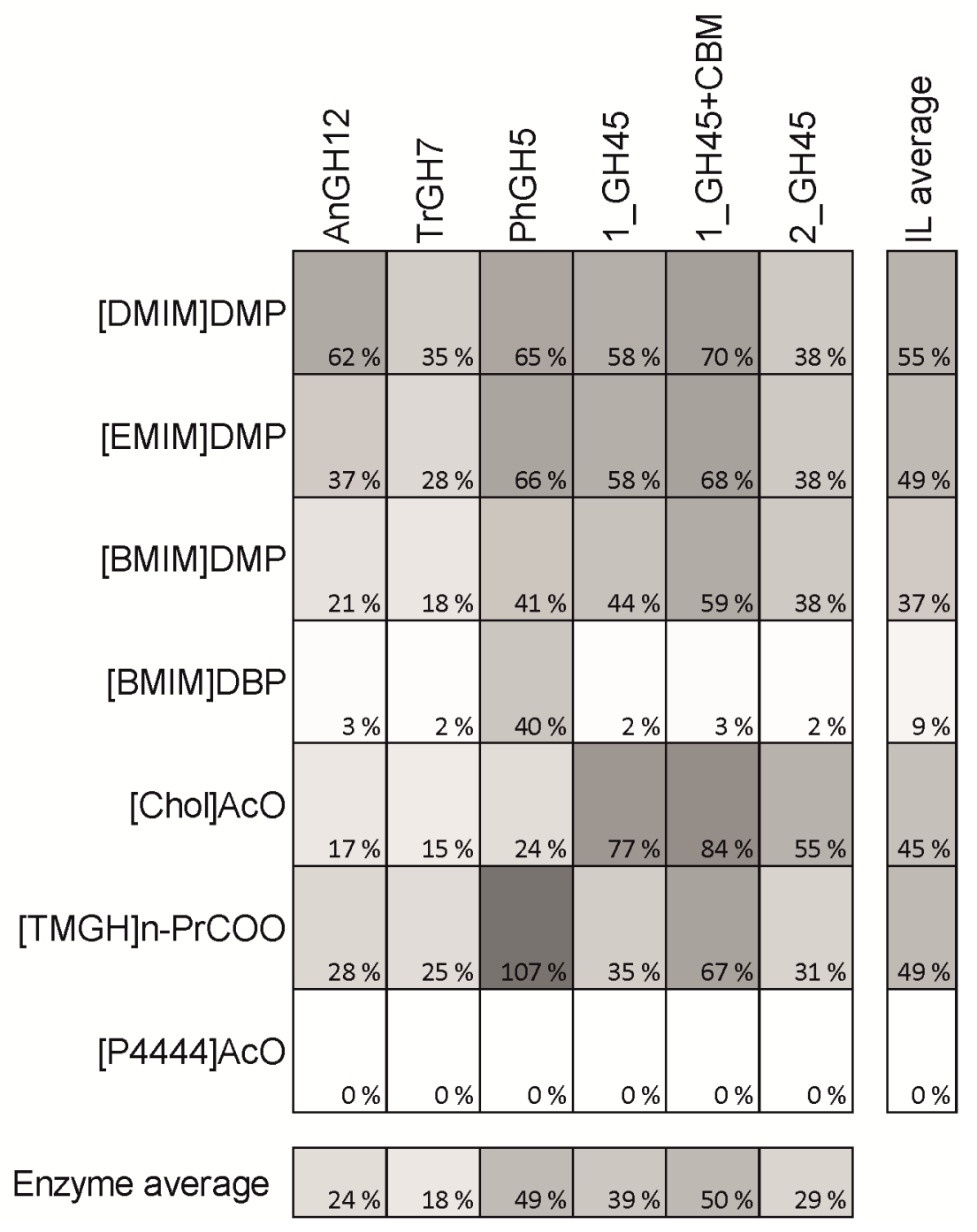

Fig. 4. Action of endoglucanases in $40 \%$ ionic liquid. Relative endoglucanase activities in $40 \%(w / v)$ ionic liquid after a $2 \mathrm{~h}$ assay. Reaction without added IL represents the $100 \%$ activity level. The darker the grey colour, the higher the enzyme activity in the IL solution. 

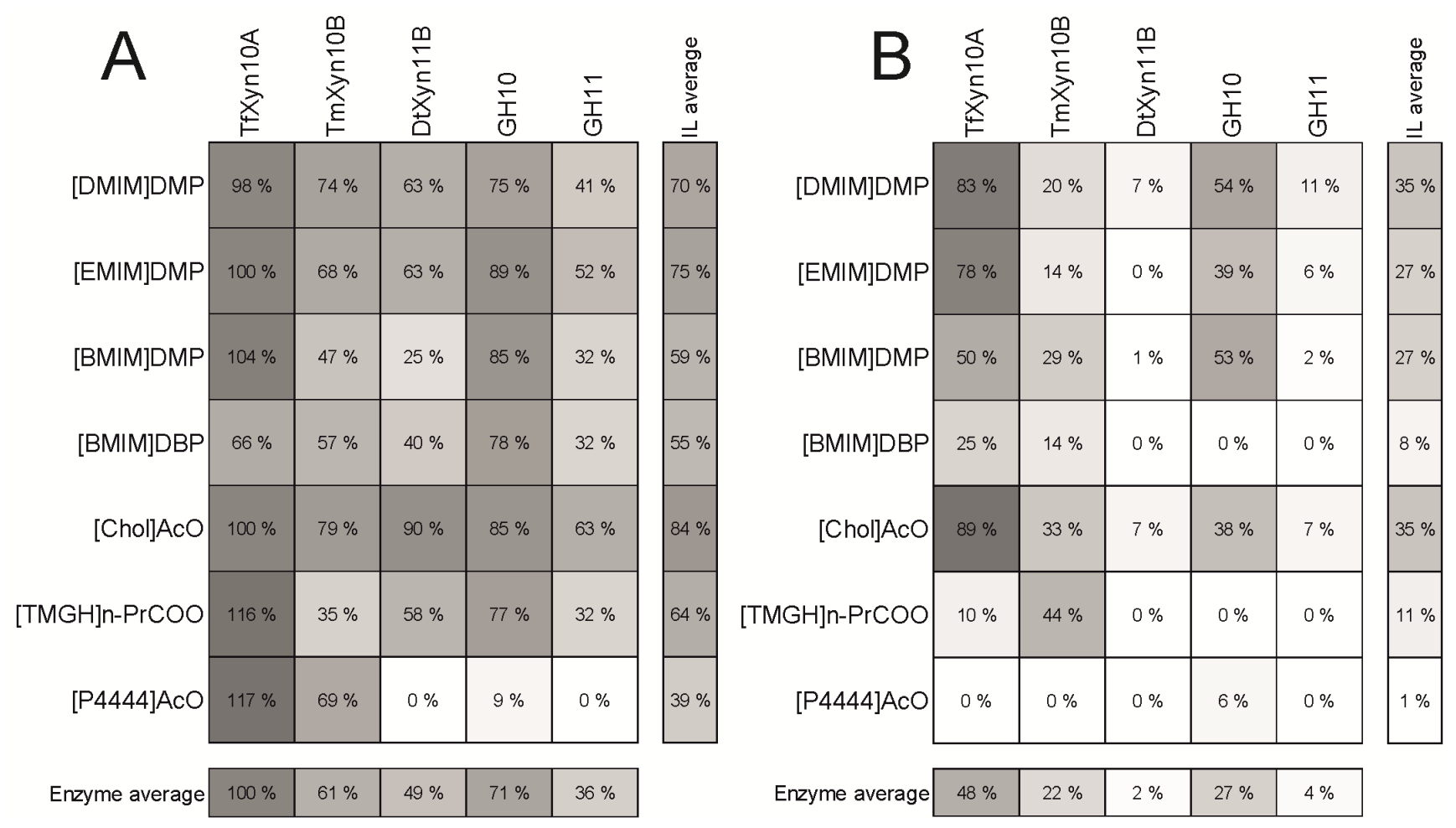

Fig. 5. Action of xylanases in $15 \%$ and $40 \%$ ionic liquid. Relative xylanase activities in A) $15 \%(\mathrm{w} / \mathrm{v})$ and B) $40 \%(\mathrm{w} / \mathrm{v})$ ionic liquid after a $2 \mathrm{~h}$ assay. Reaction without added IL represents the $100 \%$ activity level. The darker the grey colour, the higher the enzyme activity in the IL solution. 